\title{
The impact of audit quality on performance of enterprises listed on Hanoi Stock Exchange
}

\author{
Thi Thu Hien Phana, Lam Anh Lai ${ }^{b}$, Thi Tam Le ${ }^{c^{*}}$, Dung Manh Tran ${ }^{d}$ and Dang Thuong Tran
}

${ }^{a}$ University of Economics and Technical Industries, Vietnam

${ }^{b}$ Institute of World Economics and Politics, Vietnam

cThuyloi University, 175 Tay Son, Dong Da, Ha Noi, Vietnam

${ }^{d}$ National Economics University, Vietnam

${ }^{e}$ State Treasury, Que Vo, Bac Ninh, Vietnam

\begin{tabular}{l}
\hline C H R O N I C L E \\
\hline Article history: \\
Received: June 192019 \\
Received in revised format: July \\
252019 \\
Accepted: August 1, 2019 \\
Available online: \\
August 1, 2019 \\
\hline Keywords: \\
Audit quality \\
Financial performance \\
Non-financial performance \\
Vietnam
\end{tabular}

\section{A B S T R A C T}

This paper performs an empirical investigation on the effect of audit quality on performance of companies listed in Hanoi Securities Trading Floor, Vietnam. For the purpose of the article, the study conducts a comprehensive analysis of data based on 228 companies listed on Hanoi Securities Trading Floor using software SPSS 22 and Smart PLS 3.0. The results indicate that audit quality positively impacted the financial performance of the companies listed on Hanoi Securities Trading Floor. The results also indicate that audit quality also positively impacted to customer loyalty and employee satisfaction. The study also provides some recommendations for the improvement of the audit quality in Vietnam.

Vietnam

C) 2020 by the authors; licensee Growing Science, Canada

\section{Introduction}

The impact of audit quality on financial performance of companies has received significant attention from researchers. Previously, it has been shown by researchers that audit quality impacted financial performance of companies (Heil, 2012; Miettinen, 2011). Bouaziz (2012) investigated the relationship between audit committee and financial performance and reported that audit committee significantly impacted financial performance of the companies as long as the financial performance variables were measured by return of assets and return on equities. Other researchers, had more opportunities to access in auditor training processes and to carry out various tests. They reported that the bigger audit firms tend to provide audit services with higher quality (e.g. Mohammad, 2015). This is supported by Farouk and Hassan (2014) who found the size of audit firms and independence of auditors significantly impacted the financial performance of the firms. Zureigat (2010) investigated the impact of financial structure on audit quality in companies listed in Jordan. Using data of 198 companies as a sample, his logistics regression analysis stated that there was a significantly positive relationship between audit quality and financial structure. Miettinen (2011) investigated the relationship between audit quality and financial performance.

\footnotetext{
* Corresponding author. Tel.: +840984537282

E-mail address: lethitam@tlu.edu.vn (T.T. Le) 
Audit quality is measured by audit size and frequency of meetings in audit committee. The results indicated that audit quality directly impacted the performance of the firms and it also played as a mediator affecting financial performance through audit size.

With more than 750 listed companies, up to now, stock market capitalization reached over 3.9 billion Vietnam Dong, equivalent to $71.6 \%$ of GDP in 2018; the Unlisted Public Company Market (Upcom) has 804 stock codes, capitalization value reached nearly 894,000 billion Vietnam Dong; listed value of the Government bonds reached over 1.1 million billion Vietnam Dong, equivalent to $20.3 \%$ of GDP in 2018 (Ministry of Finance, 2019). Of which, there are 374 companies which listed in Hanoi Stock Exchange (HNX) with market capitalization reached nearly 190 thousand billion Vietnam Dong, decreased by 13\% compared to 2017 year-end. The average commercial value reached over 788 billion Vietnam Dong/session, increased by $12 \%$ of quantity and $28 \%$ of value compared to the same period of the last year. For stable development and good financial performance, companies listed in the Hanoi Stock Exchange should take more various measures including improvement of audit quality to increase quality of audit report for building customer confidence and employee satisfaction as well as improvement of financial performance.

The article is purposed to test the effect of audit quality on financial performance through two mediate variables consisting of customer loyalty and employee satisfaction.

\section{Literature review and developing research hypotheses}

\subsection{Financial performance}

Financial performance of companies listed in stock exchange plays an important role, this is a premise to attract capital and minimize capital cost of a company. A company with high financial performance will create prestige with investors. On the other hand, on the stock exchange, investors and managers will depend on audited financial statements of companies to specify business efficiency of listed companies. Therefore, good quality of financial statements in companies listed in the stock exchange will positively impact to financial performance of the companies. Financial performance was a multi-dimensional concept (Santos \& Brito, 2012; Salleh et al., 2006). There are various approaches to effectively measure financial performance. In our research, financial performance is approached according to theory of stakeholders and is measured in two aspects of profitability and growth rate. Profitability is always specified by net profit by calculation of accountant (Bédard \& Gedron, 2010). Profitability is measured by different rates, such as Return on equity (ROE), Price Earnings Ratio (PER) and Return on assets (ROA). Benefit measurement is necessary for all companies (Hamdan et. al, 2013). Benefit is calculated by balance of income and cost. Income is an amount earned from business activities of a company. Growth rate expresses extension of a company size regarding assets, business capital, market share, etc.

\subsection{Audit quality}

Independent audit is an examination of accounts and financial records by an independent audit firm. Independent audit is carried out by an independent individual or firm with audited company. All accounts information of a company should be examined every year after a financial year is ended. The role of an auditor is to give opinions of customer's financial statements, also to give letter of management as an advice to management board of the audited company. This will help the management board improve organization and working methods for enhancing business effectiveness of an organization.

Auditor is responsible for reviewing and assessing internal control systems which are maintained by organization, a good internal control system will prevent important incorrect report of financial statements. Professional auditors do not accept major documents in questionnaire and it is more likely that errors are discovered during the auditing. According to Barth et al. (2008), audit is an investigation or finding of evidence to allow that one opinion is formed based on financial faith and justice and other information of one person or people who are independent of the preparer aiming to increase of information reliability. According to Bouaziz (2012), audit is very important to avoid conflict of potential 
benefits between managers and stakeholders. Audit report is a communication between auditor and information user. Therefore, the report should be easy to understand, objective and not make misunderstanding to users for the process of making decisions of financial issues. Audit quality is associated with the quality of audit process aimed at preparing audit reports with quality, objectively and helping users make informed decisions based on audit reports.

\subsection{Audit quality and financial performance}

Some studies have proven that audit quality improved financial performance of a company. Afza and Nasir (2014) mentioned that independent audit quality improved operational performance of a company in the view of investors. They realized that some companies which are audited by big audit firms will release reliably, appropriately and authentically financial statements, aiming at consolidating confidence of investors in such companies. However, Bouaziz (2012) stated that high audit quality can decrease agent cost when an auditor provides reliability and sufficient index for financial statements resulting in decrease of monitor cost and supporting of higher efficiency in business activities of a company. Similarly, Hanim Fadzil et al. (2005) and Farouk and Hassan (2014), reported a positive relationship between audit quality and company performance. Therefore, it is expected that audit quality will positively impact to financial performance.

Hence, we will give research hypotheses as follows:

$\mathrm{H}_{1}$ : Good audit quality positively influences customer loyalty.

$\mathrm{H}_{2}$ : Good audit quality positively influences employee satisfaction.

$\mathrm{H}_{3}$ : Good audit quality positively influences corporate financial performance.

$\mathrm{H}_{4}$ : Customer loyalty positively influences financial performance.

$\mathrm{H}_{5}$ : Employee satisfaction positively influences financial performance.

\subsection{The Lending Credibility Theory}

The theory specified that main functions of audit is consolidated the reliability of a financial statements. The reliability of users will be increased when using audited financial statements instead of financial statements represented by management board. Therefore, the management board should use audited financial statements to improve confidence of stakeholders in its management activities. Users will be benefited from increasing confidence; such benefits often are considered as quality of investment decisions improved basing on reliable information (Hayes et al. 2005). Audited financial statements strengthened principal agent relationship and unbalanced information. Akinbuli (2010) declared that an audited financial statement can improve confidence of stakeholders in management activities. It means that companies with reliably and consistently financial statements will be easily invested and borrowed by investors and creditors.

\subsection{The Policeman Theory}

According to the theory, an auditor plays a role of security officer to ensure accuracy and preventability and fraud detection. The theory will help an auditor detect and prevent misrepresentation and fraud in organizations. Management board should establish and maintain strong internal control system to strengthen prevention, detection of fraud and any abnormal case in an organization. An auditor is not responsible for detecting fraud unless a specific agreement is made and signed by the auditor and management board of audited company to do so. However, if audit process is worked in process, auditor will detect fraud occurred by audited company. Key responsibility of an auditor is to verify the truthfulness of a financial statements and provide reasonable assurance. However, fraud detection is also a hot topic in a discussion about auditor's responsibilities and such discussion will be often organized after fraud events in financial statements are found and pressured to increase responsibilities of auditors in fraud detection (Hayes et al, 2005). 


\section{Research methodology and research model}

\subsection{Research sample}

Research sample is important in a research (Henseler et al. 2009). The bigger the sample size, the more accuracy of the analyzed data and the better presentation for entire research. However, based on the characteristics of a research, scientists have provided criteria for selection of various sample size. Smart PLS, the second generation software with advantages of data processing for small sample size is used, therefore, our scale of research sample is 228 companies listed in Hanoi Stock Exchange.

\subsection{Research model}

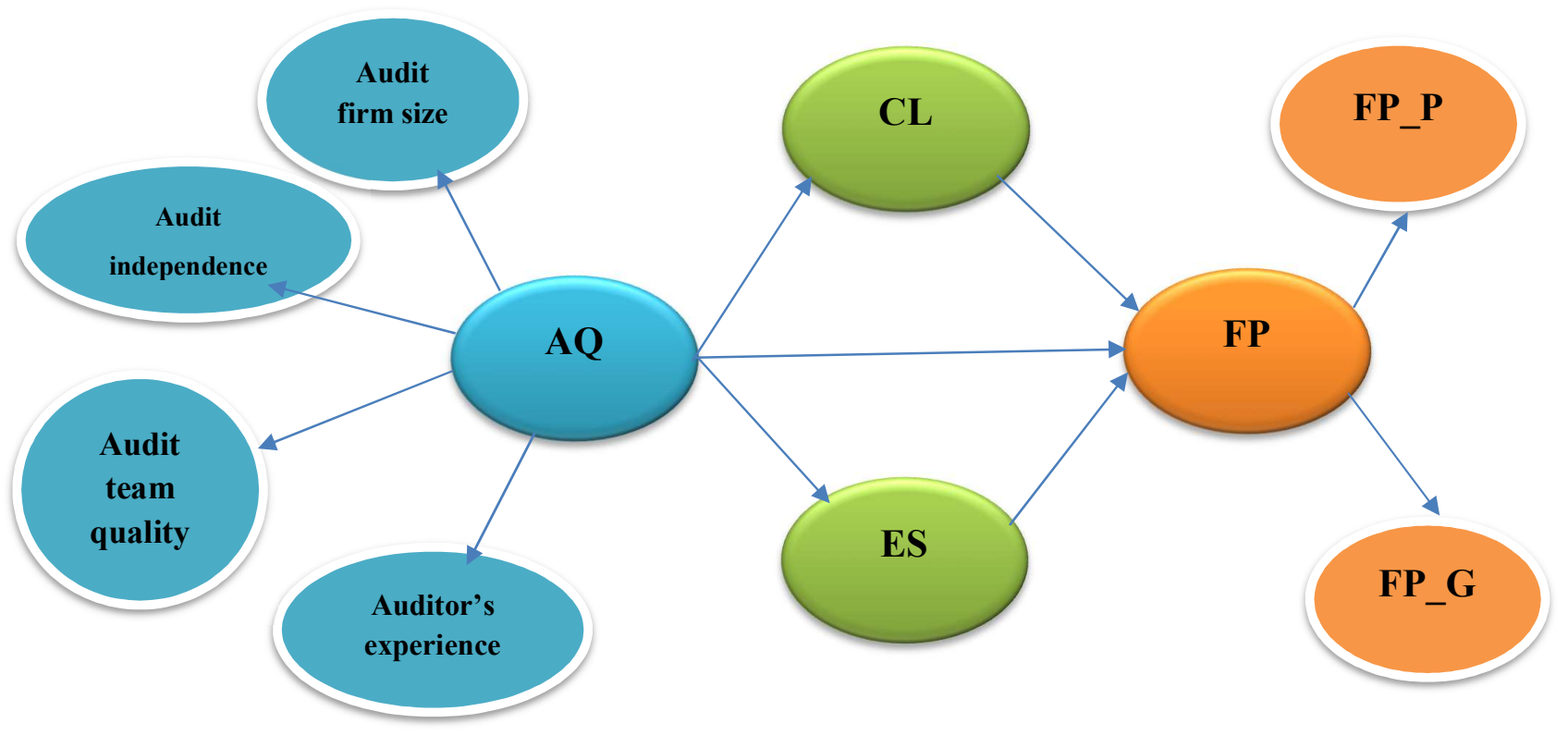

Fig. 1. Research model

In this study, audit quality is measured through 4 aspects including audit firm size, independence of auditor, qualification of auditor group and experiences of auditor. Non-financial performance includes two aspects: Customer orientation is customer loyalty and orientation to employee is employee satisfaction. Financial performance means final latent variable that is measured through 2 aspects including profitability and growth rate.

Latent variable and scale

Audit firm size

Audit firm size can impact the benefit report of a company. Branch network of audit firm can impact benefit report of a company. The number of partners of audit firm impact the benefit of a company.

Independence of auditor

Remuneration of auditor is associated with financial performance of the company. Management of the company can impact decision-making of auditor and management board will keep one auditor when financial activities operating effectively.

\section{Qualification of auditor group}

Qualification of audit partners can impact audit quality of the reported financial result. Membership of professional organizations impact the audit quality of reported financial result. The number of qualified auditors impact to quality of reported financial statements. 


\section{Audit experience}

Length of service of audit firms impact the quality of the reported financial statements. The number of qualified auditors in a group will impact the quality of reported financial statements. Experiences of an auditor working in international environment impact the audit quality of reported financial performance.

\section{Financial performance}

This item is measured by two aspects including profitability and growth rate as defined in the research of Santos \& Bristo (2012).

\section{Non-financial performance}

Non-financial performance includes 2 variables: customer loyalty (CL) and employee satisfaction (ES). Such observed variables are measured by scale of Defond and Jiambalvo (1993) and Sayyar (2015). The observed variables of the scale are measured by 5-point Likert scale.

\section{Loyal customer (customer loyalty)}

The measure of customer loyalty is measured by the following questions:

Your company has regular and periodic assessment measures for customer services.

Your company develops products and services based on sufficient information of market and customer.

Your company always considers benefits of customer as top priority.

You believe that your company's existence is for providing customer services.

\section{Employee satisfaction}

You are proud to tell anyone that you are working in the company.

You will introduce everyone to your company with good words.

Leaders of your company are qualified and committed to solve problems faced with by the company.

You are trusted to make significant decisions in daily activities.

You are satisfied with salary paid by the company.

\subsection{Analysis method}

To analyze data, SPSS 22 and Smart PLS 3.0 are used. First, after data is collected, it is classified and imported in excel table, then they are imported to SPSS 22 software to test the reliability of scale and remove scales that do not satisfy some requirement conditions. Finally, we enter reliable data to Smart PLS 3.0 software to test the research hypotheses.

Standard for scale reliability test is based on Cronbach Alpha coefficient and item-total correlation. The scale is satisfied when Cronbach Alpha coefficient is greater than 0.7 and item-total correlation is bigger than 0.3. Next, we assessed convergent value and differentiation value as well as appropriateness of research model and research data.

\section{Research result}

Result of scale reliability test pointed out that all scales are satisfied conditions including Cronbach Alpha coefficient $>0.7$ and item-total correlation $>0.3$. Therefore, all scales are satisfied to carry out the next analysis.

The result of scale reliability test are in Table 1 as follows: 
Table 1

Construct Reliability and Validity

\begin{tabular}{lcccc}
\hline & Cronbach's Alpha & rho_A & Composite Reliability & Average Variance Extracted (AVE) \\
\hline Audit firm size & 0.755 & 0.718 & 0.773 & 0.776 \\
Employee satisfy & 0.838 & 0.848 & 0.839 & 0.836 \\
FP_G & 0.932 & 0.942 & 0.930 & 0.772 \\
FP_P & 0.923 & 0.941 & 0.926 & 0.809 \\
Financial performance & 0.949 & 0.950 & 0.949 & 0.850 \\
Quality of audit & 0.920 & 0.922 & 0.920 & 0.898 \\
audit team quality & 0.530 & 0.795 & 0.765 & 0.752 \\
auditor's experience & 0.874 & 0.874 & 0.757 & 0.875 \\
auditor's independence & 0.829 & 0.768 & 0.720 & 0.821 \\
customer loyalty & 0.945 & 0.947 & 0.945 & 0.774 \\
\hline
\end{tabular}

From Table 1 shows that potential variables are satisfied with Cronbach Alpha coefficients $>0.7$ and AVE coefficient $>0.5$. Thus, these potential variables are satisfied to be included in the next analysis as shown in Table 2 below.

Table 2

Discriminant Validity (Fornell-Larcker Criterion)

\begin{tabular}{|c|c|c|c|c|c|c|c|c|c|c|}
\hline & $\begin{array}{l}\text { Audit firm } \\
\text { size }\end{array}$ & $\begin{array}{l}\text { Employee } \\
\text { satisfy }\end{array}$ & FP_G & FP_P & $\begin{array}{c}\text { Financial } \\
\text { performance }\end{array}$ & $\begin{array}{l}\text { Quality } \\
\text { of audit }\end{array}$ & $\begin{array}{l}\text { audit team } \\
\text { quality }\end{array}$ & $\begin{array}{l}\text { auditor's } \\
\text { experience }\end{array}$ & $\begin{array}{c}\text { auditor's } \\
\text { independence }\end{array}$ & $\begin{array}{c}\text { customer } \\
\text { loyalty }\end{array}$ \\
\hline Audit firm size & 0.881 & & & & & & & & & \\
\hline Employee satisfy & 0.231 & 0.914 & & & & & & & & \\
\hline FP G & 0.201 & 0.235 & 0.878 & & & & & & & \\
\hline FP_P & 0.182 & 0.248 & 0.393 & 0.899 & & & & & & \\
\hline Financial performance & 0.241 & 0.280 & 0.325 & 0.358 & 0.921 & & & & & \\
\hline Quality of audit & 0.114 & 0.223 & 0.379 & 0.386 & 0.512 & 0.947 & & & & \\
\hline audit team quality & 0.066 & 0.186 & 0.271 & 0.382 & 0.415 & 0.452 & 0.867 & & & \\
\hline auditor's experience & 0.004 & 0.229 & 0.233 & 0.274 & 0.379 & 0.471 & 0.244 & 0.935 & & \\
\hline auditor's independence & 0.050 & 0.152 & 0.124 & 0.103 & 0.356 & 0.473 & 0.274 & 0.023 & 0.906 & \\
\hline customer loyalty & 0.159 & 0.356 & 0.272 & 0.284 & 0.339 & 0.236 & 0.154 & 0.194 & 0.127 & 0.880 \\
\hline
\end{tabular}

The results of Table 1 and Table 2 show that research variables and scale are satisfied to implement for the next analysis. The authors examined the research hypotheses and the results are given in Fig. 2. As we can observe, audit quality significantly impacts the financial performance at high level of 0.367 and $1 \%$ significance level $(\mathrm{P}$-value $=0.000)$. Also, audit quality positively influences nonfinancial performance at medium level. More specifically, audit quality positively impacts the employee satisfaction at impact level of 0.221 and $1 \%$ significance level $(\mathrm{P}$-value $=0,000)$. Moreover, audit quality positively impacts the employee satisfaction at medium level of 0.197 and $1 \%$ significance level (P-value $=0.000)$. Employee satisfaction positively impacts the financial performance at impact level of 0.094 and $5 \%$ significance level ( $\mathrm{P}$-value $=0,040)$. Customer royalty positively impacts the financial performance at the impact level of 0.174 and $1 \%$ significance level $(\mathrm{P}$-value $=0,000)$. Therefore, all hypotheses are supported.

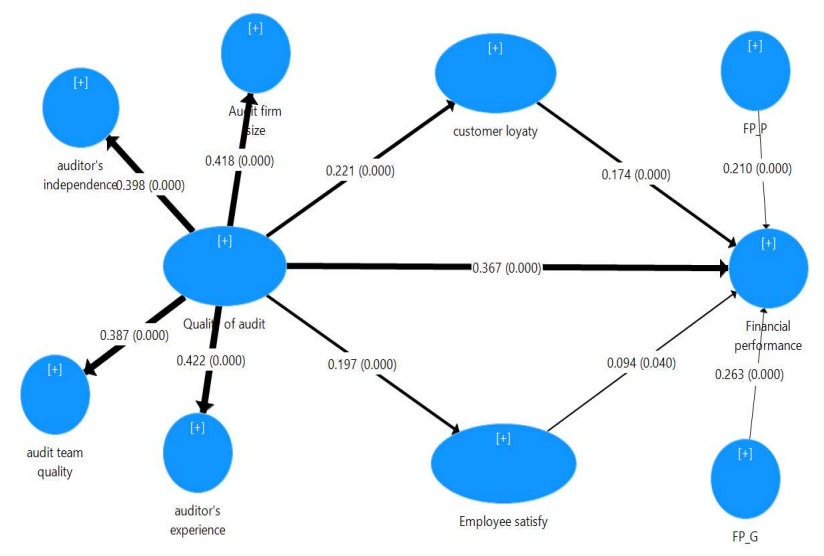

Fig. 2. Result of testing the hypotheses 


\section{Conclusion}

The results have shown that audit quality significantly impacted the financial performance and non-financial performance of the companies listed on Hanoi Securities Trading Floor. Theory of security and theory of loan are supported by the result as well. Also, the research results are consistent with the findings released by Chi and Huang (2005) and Alali (2011). Therefore, authors propose some recommendations for improving audit quality of audit firms as follows:

Improvement of extensive professional experiences of auditor/auditor group: Auditors should acknowledge that, extensive professional experiences are the most key important factor to help them carry out a quality audit and thus, auditors are able to face with less occupational risks or avoid making mistakes or lawsuits, if any, affecting their occupational prestige. Therefore, auditors are required to regularly improve extensive professional experiences to meet requirement of extensive audit. Scope of business in a listed company is different, such as: trading in bank sector, financial consultancy, real estate, construction, while survey results have shown that this is an important external factor influencing the audit quality of an auditor. Therefore, auditing the listed companies is involved with a complicated auditing environment requiring dynamics, qualification, legal knowledge, etc., therefore, auditors should accumulate experiences by themselves of specific sector for understanding scope of business and financial statements of listed companies.

Completion of quality control system of audit firm, of which specially paying attention to set up an effective quality control process as well as giving prominence to role of independent auditor in an audit firm for each audit (the most appreciated two criteria in Management policy). Quality control in internal audit firm improves quality of audit services, assurance services and related services. According to ISA 220, internal control system in an audit firm for each audit should include: (i) To agree, maintain customer relationship and audit contract; (ii) To assign auditor group; (iii) To implement audit; (iv) To monitor; (v) Audit documents, records. Quality control of entire company should comply with VSQC1, accordingly, quality control system of an audit firm should include policies and procedures for the following contents: (i) Responsibilities of Board of Directors for quality in audit firm; (ii) Requirements of occupational ethics; (iii) Maintenance of customer relationship and service contracts; (iv) Human resources; (v) Implementation of contract service; (vi) Monitor; (vii) Control of service contract quality.

We hope the results of this survey are useful for researchers to do similar studies by extending the ideas given in this research.

\section{References}

Afza, T., \& Nazir, M. S. (2014). Audit quality and firm value: A case of Pakistan. Research Journal of Applied Sciences, Engineering and Technology, 7(9), 1803-1810.

Akinbuli, S. F. (2010). The effect of audit expectation gap on the work of auditors, the profession and users of financial information. The Nigerian Accountant, 43(4), 37-47.

Alali, F. (2011). Audit fees and discretionary accruals: compensation structure effect. Managerial Auditing Journal, 26(2), 90-113.

Barth, M. E., Landsman, W. R., \& Lang, M. H. (2008). International accounting standards and accounting quality. Journal of Accounting Research, 46(3), 467-498.

Bédard, J., Chtourou, S. M., \& Courteau, L. (2004). The effect of audit committee expertise, independence, and activity on aggressive earnings management. Auditing: A Journal of Practice \& Theory, 23(2), 13-35.

Bouaziz, Z. (2012). The impact of auditor size on financial performance of Tunisian companies. Paper presented at the Faculty of Economics and Management. Sfax University, Tunisia.

Chi, W., \& Huang, H. (2005). Discretionary Accruals, Audit-Firm Tenure and AuditPartner Tenure: Empirical Evidence from Taiwan. Journal of Contemporary accounting \& Economics, 1, 65-92. 
Defond, M. L., \& Jiambalvo, J. (1993). Factors related to auditor-client disagreements over incomeincreasing accounting methods. Contemporary Accounting Research, 9(2), 415-431.

Farouk, M. A., \& Hassan, S. U. (2014). Impact of audit quality and financial performance of quoted cement firms in Nigeria. International Journal of Accounting and Taxation, 2(2), 1-22.

Hamdan, A. M., Mushtaha, S., \& Musleh Al-Sartawi, A. (2013). The audit committee characteristics and earnings quality: Evidence from Jordan. Australasian Accounting Business and Finance Journal, 7(4), 48-80.

Hanim Fadzil, F., Haron, H., \& Jantan, M. (2005). Internal auditing practices and internal control system. Managerial Auditing Journal, 20(8), 844-866.

Hayes, R. Dassen, R. Schilder, A. \& Wallage, P. (2005). Principles Of Auditing: An Introduction to International Standards on Auditing, $2^{\text {nd }}$ ed., Prentice Hall.

Henseler, J., Ringle, C. M., \& Sinkovics, R. R. (2009). The use of partial least squares path modeling in international marketing. In New challenges to international marketing (pp. 277-319). Emerald Group Publishing Limited.

Heil, D. (2012). The influence of the auditor on the earnings quality of their clients. Department of Accounting, Auditing and Control, Erasmus University, Rotterdam.

Miettinen, J. (2011). The role of audit quality on the relationship between auditee's agency problems and financial information quality. Paper presented at the Department of Accounting and Finance, University of Vaasa, Finland.

Mohammad, A.J. (2015). Audit committee characteristics improving financial reporting quality among Malaysian listed company. European Journal of Social Science Review, 1(2), 18-28.

Salleh, Z., Stewart, J., \& Manson, S. (2006). On the impact of board composition and ethnicity on audit quality: Evidence from Malaysian companies. Management \& Accounting Review (MAR), 5(2), 6183.

Santos, J. B., \& Brito, L. A. L. (2012). Toward a subjective measurement model for firm performance. BAR-Brazilian Administration Review, 9(SPE), 95-117.

Sayyar, H. (2015). The Impact of Audit Quality on Firm Performance: Evidence from Malaysia. International Business School, Universiti Teknologi Malaysia, June 2015. Available: http://www.akademiabaru.com/wvsocial/temp/acc4a.pdf [Accessed 17 September 2015].

Zureigat, Q. (2010). The Effect of Modified Auditors Opinions on Shares Prices Evidence from Amman Stock Exchange. Jordan Journal of Business Administration, 6(2), 210-224.

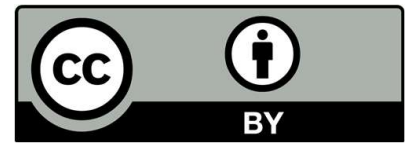

(C) 2020 by the authors; licensee Growing Science, Canada. This is an open access article distributed under the terms and conditions of the Creative Commons Attribution (CCBY) license (http://creativecommons.org/licenses/by/4.0/). 